\title{
Self-Control Training To Reduce Gadget Addiction In Teens
}

\author{
Nury Fitri Astuti*, Siti Urbayatun* \\ "Magister Psikologi Profesi Universitas Ahmad Dahlan \\ Jl. Kapas 9, Semaki, Umbulharjo, Yogyakarta \\ nuryfitri23@gmail.com \\ DOI: 10.29322/IJSRP.12.01.2022.p12113 \\ http://dx.doi.org/10.29322/IJSRP.12.01.2022.p12113
}

\begin{abstract}
Nowadays the gadget is favored by the community, especially among adolescents. The ease of accessing gadgets often makes teenagers lack control in using it. In addition to the use of gadgets with uncontrolled time, teens also often use gadgets in inappropriate situations. Some teachers complain that students often use gadgets during class so that it disrupts ongoing teaching and learning activities. The purpose of this study is to train adolescents to reduce the use of gadgets by using behavior therapy techniques, that is self-control programs. This study uses a one group pre-posttest design. The subjects in this study are of 7 students who often use gadgets, especially during class. This research was analyzed using Wilcoxon with SPSS.16. There was a significant difference (Z $=-2.375 ; \mathrm{P}=0.018 \leq 0.05)$ in the score of gadget use before therapy $(\mathrm{M}=1.57 ; \mathrm{SD}=8.80)$ with the score of gadget use after therapy $(\mathrm{M}=1.42 ; \mathrm{SD}=0.63)$. Self-control programs are very effective in reducing the use of gadgets in adolescents.
\end{abstract}

Index Terms- gadget; teenager; adolescents; self-control

\section{INTRODUCTION}

adget users in 2013 with $27 \%$ of the world's population reaching 1.9 billion and it is predicted that the number of gadget users will continue to increase to 5.6 billion in 2019 (Pandey, Ratag, \& Langi, 2019). In Southeast Asia, in August 2014 there were 120 Gillion gadget users, which has increased by $44 \%$ each year, while data from the sales of gadgets in Indonesia in 2014 with active users reached 47 million users (Riani, 2016).

Gadget addicts in 2014 in Indonesia increased from 1.4 billion gadget users, 176 million of whom were gadget addicts, this figure increased by $123 \%$ compared to 2013 which was only 79 million people (Purwanto, Atina, \& Desylawati, 2017). Users of online game applications through gadgets and having experienced device dependence in Indonesia in 2017 are indicated to be 6 million with teenagers of approximately $40 \%$ (Sari \& Rajayanti, 2017).

Kominfo (2017) states that as many as $65.34 \%$ of smartphone users are 9-19 years old. As much as $79.56 \%$ of smartphone users are high school teenagers. The location of smartphone use in schools is $7.16 \%$ and as much as $89.63 \%$ outside the home, school/campus, and office environment. $19.07 \%$ of individuals using smartphones for 5-10 hours a day.

As many as $43.90 \%$ of internet users aged 9-19 years and $61.64 \%$ of internet users are at the high school level. Activities undertaken while using the internet include e-mail, web browsing, streaming, and online shopping. The use of computers when not connected to the internet is $29.96 \%$ for watching videos and listening to music. Meanwhile, $24.90 \%$ for playing games. $95.68 \%$ of individuals use smartphones to communicate and $41.06 \%$ of individuals use smartphones for entertainment when not connected to the internet. $93.46 \%$ of individuals use smartphones to communicate, and $65.29 \%$ of individuals use smartphones for entertainment when connected to the internet. $97.5 \%$ of social media users are at the high school level, and $93.52 \%$ of social media users are aged 9-19 years (Kominfo, 2017).

Matondang (2015) states that teenagers use cellphones more than 5-10 times and spend 4-12 hours in one day using cellphones. Fadilah (2015) states that several factors influence adolescents in using gadgets. These factors include Rampant advertisements in the world of television and on social media, gadgets displaying attractive features, the sophistication of gadgets, affordability of gadgets, and the environment. Kotler (2007) also mentions several other factors that influence adolescents in using gadgets, including cultural factors, social factors, and personal factors.

Yuwanto (Agusta, 2016) argues that four factors cause smartphone addiction, namely: internal factors (including high levels of sensation seeking, low self-esteem, high extraversion personality, and low self-control), situational factors, social factors, and external factors.

Sa'adah (2015) states that students use gadget information technology intensively, regardless of time and space. Students use gadgets when studying, during recess and when they come home from school. The use of gadgets is also supported by the provision of hotspots. 
The use of gadgets among teenagers will certainly have an impact on adolescents. The impact that occurs is in the form of positive and negative impacts. Sa'adah (2015) mentions the positive impact of using gadgets, namely: making more friends, and making it easier to interact over long distances. While the negative impacts of using gadgets are: losing the meaning of face-to-face interactions, non-cooperation between friends, living individually, and living in cyberspace.

The positive impact of using gadgets on adolescents according to Harfiyanto, et al, (2015), namely: making it easier to interact with many people via social media, shortening distance and time, long-distance relationships are no longer a problem and an obstacle, and make it easier for teenagers to consult lessons and assignments - tasks that have not been understood. In addition to the positive impact, the use of gadgets on adolescents also has negative impacts, including Generating more time to spend on gadgets, so that teenagers spend more time communicating on social media compared to studying, applications in gadgets make teenagers more selfish (Harfiyanto, et al, 2015). Winoto (2013) mentions some of the negative impacts of using gadgets on adolescents, including Teens become addicted to playing gadgets, gadgets make it easier for teenagers to access various sites that are not properly accessed, social media in gadgets often causes various cases such as kidnapping and rape, teenagers often cannot control their words such as using harsh words, taunts and ridicule their peers, and adolescents are less able to build their social skills and abilities. Ameliola and Nugraha (2013) state that gadgets make teenagers lazy to move and do activities.

Several effective therapies to control gadget use in adolescents, one of which is self-control. According to Beck (Gunarsa, 2009) selfcontrol is an individual's ability to withstand a momentary desire or urge that is contrary to behavior that is not by social norms. according to Chaplin (2006) self-control is the ability to guide one's behavior, the ability to suppress or block impulses or impulsive behavior.

According to Averill (Thalib, 2017), in general, self-control is divided into three main aspects, namely: behavioral control, cognitive control, and decision control. Calhoun \& Acocella (2004) suggested three basic aspects of self-control, including Making considerations of choices, choosing one of the two behaviors, manipulating stimuli to make a behavior more likely to be done, and other behavior less likely.

Based on the self-control scale according to Tangney, Baumeister, and Boone (Widjaja, 2015) 5 factors are measured in self-control, namely: Self-discipline, deliberate / non-impulsive, health habits, work ethic, reliability.

\section{INDETIFY, RESEARCH AND COLLECT IDEA}

Research design is a design for how research is carried out. The research design used in this study was a one group pretest-posttest design. According to Sugiyono (2012) one group pretest and posttest design is a technique to determine the effects before and after treatment. In this design, before the treatment is given first the sample is given a pretest (initial test) and at the end of learning the sample is given a posttest (final test).

\section{A. Participants}

This research was conducted at a high school in Imogiri, Yogyakarta. Participants in this study were 7 students who were obtained using a screening process. All respondents are class X students aged 14 to 16 years.

\section{B. Procedure}

Data collection

Data collection was carried out by observation, interview, and filling the scale. Participants were selected through a screening process and obtained informed consent for the FGD process. Before conducting the screening process, the researcher conducted interviews with the counseling teacher and several homeroom teachers. After obtaining the interview data, the researcher screened the students in the class using a questionnaire distributed to 22 students. Based on the results of the questionnaires distributed, the results obtained were that $13.63 \%$ of female students had behavioral disorders, $18.18 \%$ of female students experienced anxiety. As many as $13.63 \%$ of female students experienced anxiety and depression. As many as $22.72 \%$ of female students became the perpetrators and victims of bullying. As well as $27.27 \%$ of female students are dating and addicted to gadgets. Based on the results of discussions with supervisors and counselors at school, the focus of the problem regarding gadget addiction was chosen. Researchers then divided the scale of gadget addiction among adolescents. The scale was distributed to 22 students. The researcher then conducted a more in-depth interview about the use of student gadgets to homeroom teachers and counseling teachers. Based on the results of filling in the scale, 7 students were obtained who would become the subjects in this study. 7 students were then collected in a focus group discussion group. The seven students provided information that they often use their free time to use gadgets. The gadgets used are smartphones and laptops. The seven students use gadgets at school and home. The reason students use gadgets is to chat with other people, look for the 
latest news information, especially those related to information, feel bored with their surroundings, look for entertainment, check social media accounts, and find materials or assignments from school. Participants do not realize the time wasted while using the gadget. When using gadgets, participants felt that they spent a short time. However, when asked to calculate the time spent using gadgets from waking up to going to bed, participants then realized that they had been using gadgets for or even more than 6 hours.

Participants use gadgets both at home, at school, and elsewhere. When using gadgets, participants cannot control the time limit for using gadgets. The participants did not realize how much time they spent using the gadget. Even when hanging out with friends, participants also used gadgets and only realized that there was no chat in the group. Participants also provided information that apart from themselves, their other friends also used gadgets when they gathered.

When the teacher is unable to attend to teach, the participants prefer to spend that time using gadgets. When using gadgets, participants open social media accounts and look for the latest information or reply to chats from other people. 3 participants have tried to reduce their use of gadgets by deactivating their smartphones for 2 to 3 days. However, this method is deemed ineffective. They could not hold back their desire and curiosity for the latest news, so they reactivated and used their gadgets.

The participants were then given material about self-control and the use of self-control. After the material was given, the participants were then given an assignment that had to be filled in for the next week.

Table 1. Formulation of intervention design.

\begin{tabular}{|l|l|}
\hline \multicolumn{1}{|c|}{ Forms of activity } & \multicolumn{1}{|c|}{ Purpose } \\
\hline \multirow{5}{*}{ Session I Psychoeducation } & $\begin{array}{l}\text { 1. Participants gain an understanding of the dynamics of the problems that } \\
\text { occur. } \\
\text { 2. Participants understand the meaning, characteristics/symptoms, causes, and } \\
\text { effects of gadget addiction. } \\
\text { 3. Participants gain knowledge and understanding of how to reduce gadget } \\
\text { addiction. }\end{array}$ \\
\hline Session II Self-control training & $\begin{array}{l}\text { 2. Participants make efforts to reduce gadget addiction. } \\
\text { 3. Participants are allowed to be able to apply the self-control assignment sheet. }\end{array}$ \\
\hline \multirow{3}{*}{$\begin{array}{l}\text { 1. Knowing the progress of the participant's condition after practicing self- } \\
\text { control techniques. 2. Knowing the participants' opinions about the group } \\
\text { therapy process that has been carried out in overcoming the gadget addiction } \\
\text { they have experienced. }\end{array}$}
\end{tabular}

Data analysis

Data analysis used non-parametric analysis, namely Wilcoxon (Wilcoxon signed-rank test). The pre-test scores and post-test scores were given using SPSS 16.0 for windows.

\section{RESULTS AND DISCUSSION}

There is a significant difference $(\mathrm{Z}=-2.375 ; \mathrm{P}=0.018 \leq 0.05)$ in the score for using gadgets before therapy $(\mathrm{M}=1.57 ; \mathrm{SD}=8.80)$ and the scores for using gadgets after therapy $(\mathrm{M}=1.42 ; \mathrm{SD}=0.63)$.

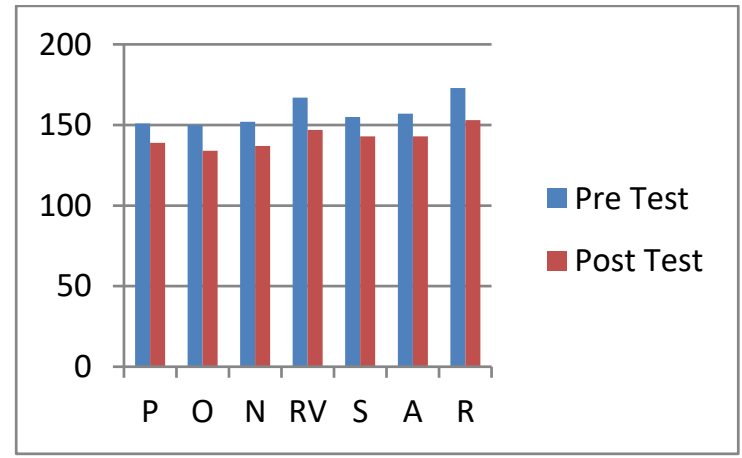

Figure 1. Graph of the pretest and posttest scores

Based on the results of the graph above, shows that there is a decrease in the scale score of gadget use before and after the intervention is given. The largest decrease was experienced by subjects $\mathrm{N}$ and $\mathrm{R}$. 
The intervention program implemented was successful in reducing the use of gadgets among adolescents. Participants have a desire and have tried to do one way to reduce gadget usage, namely by not activating the gadget for 3 days. However, this method did not work. When using gadgets, participants felt they could not control the time spent using gadgets. Often participants do not realize that the time spent using gadgets is more than 6 hours.

This intervention program achieved its target because of the strong desire of the participants to take part in the self-control program. Participants considered that self-control was very effective in reducing gadget use in adolescents. This happened because several participants had tried to reduce their use of gadgets. However, this did not work because the methods used were less effective. The success of this intervention program was also influenced by the strong willingness of the participants to overcome discomfort when not using gadgets. This is very necessary because participants are accustomed to using their spare time to use gadgets. However, in this program, participants are asked to set a time limit for using the gadget. When the time for using gadgets is limited, participants feel confused about finding activities to fill their free time and divert their desire to use gadgets.

Dewangga and Makmuroh (2015) state that there is a negative relationship between self-control and cyber sexual addiction. This means that there is a close negative relationship between self-control and cyber sexual addiction, which shows that the lower selfcontrol, the higher the level of cyber sexual addiction.

Tripambudi and Endang (2018) show that there is a significant negative relationship between self-control and the consumer behavior of gadget buyers ( $r x y==0.207 ; \mathrm{p}=0.003$ ). The higher the self-control, the lower the consumer purchasing behavior of gadgets, and the lower the self-control, the higher the consumer buying behavior of gadgets. Self-control made an effective contribution of $4.3 \%$ for consumer gadget purchases.

\section{CONCLUSION}

Self-control training is very effective at reducing gadget use in adolescents. The writer/intervention provider is then advised to actively communicate with the homeroom teacher and counseling teachers regarding the schedule of activities at school and about the intervention activities that will be carried out. Authors/intervention givers are also advised to be able to motivate so that participants feel a need and are willing to follow the intervention process that will be carried out. So, all participants can follow the entire intervention process well.

\section{REFERENCES}

Agusta, D. (2016). Faktor-Faktor Resiko Kecanduan Menggunakan Smartphone pada Siswa di SMK Negeri 1 Kalasan. Jurnal Riset Mahasiswa Bimbingan dan Konseling, Vol.5, No.3. Yogyakarta: Universitas Negeri Yogyakarta.

Ameliola, S., \& Nugraha, D.H. (2013). Perkembangan Media Informasi dan Teknologi Terhadap Anak dalam Era Globalisasi. Prosiding The $5^{\text {th }}$ International Conference on Indonesia Studies: "Ethnicity and Globalization". Malang: Universitas Brawijaya.

Baumeister, R.F. (2002). Handbook of Social Psychology (4th Eds). New York: McGraw-Hill.

Bian, M. \& Leung, L. (2014). Linking Lonelliness, Shyness and Smartphone Addiction Symptom, and Patterns of Smartphone Use to Social Capital. Social Science Computer Review. August 21, 2014. 1-19. China: The Chinese Univerity of Hong Kong.

Borba, M. (2008). Membangun Kecerdasan Moral. Jakarta: Gramedia.

Calhoun, J.F. \& Acocella, J.R. (2004). Psikologi tentang Penyesuaian Hubungan Kemanusiaan. Edisi Tiga. Semarang: IKIP Semarang Press.

Chaplin J.P. (2002). Kamus Lengkap Psikologi. Cetakan Keenam. Penerjemah: Kartiko. Jakarta: PT. Raja Grafika Persada.

Chaplin, J.P. (2006). Kamus Lengkap Psikologi. Jakarta: PT. Raja Grafindo.

Chiu, Shao-I. (2014). The Relationship Between Life Stress and Smartphone Addiction on Taiwanese University Student: A Mediation Model of Learning Self Efficacy and Social Efficacy. Computers in Human Behavior, 34, (2014) 49-57. Taiwan: Center of General Education at Taipei College of Maritime Technology.

Dewangga \& Makmuroh. (2015). Hubungan Antara Kontrol Diri dengan Cybersexual Addiction pada Siswa SMP di Orange-net Bandung. Prosiding Penelitian Sivitas Akademika Unisba (Sosial dan Humaniora). Gelombang 2, Tahun Akademik 2014-2015. Bandung: Fakultas Psikologi Universitas Islam Bandung.

Dewi A.C. \& Rendhy S. (2017). Strategi Layanan Bimbingan dan Konseling untuk Mereduksi Dampak Kecanduan Media Sosial pada Anak. Prosiding Seminar Nasional Peran Bimbingan dan Konseling Penguatan Pendidikan Karakter. Yogyakarta: Universitas Ahmad Dahlan. 
Fadilah, R. (2015). Perilaku Konsumtif Mahasiswa UGM dalam Penggunaan Gadget. Skripsi. Yogyakarta: Fakultas Sosiologi Universitas Gadjah Mada.

Frisnawati, A. (2012). Hubungan antara Intensitas Menonton Reality Show dengan Kecenderungan Perilaku Prososial. Empathy Vol. 1: 50 - 54. Yogyakarta: Fakultas Psikologi Universitas Ahmad Dahlan.

Ghufron, M.N. \& Risnawita, R. (2010). Teori-teori Psikologi. Yogyakarta: Ar-Ruzz Media.

Gunarsa, S.D. (2009). Dari Anak sampai Usia Lanjut: Bunga Rampai Psikologi Perkembangan. Jakarta: PT. BPK Gunung Mulia.

Harfiyanto, Doni, dkk. (2015). Pola Interaksi Sosial Siswa Pengguna Gadget di SMA Negeri 1 Semarang. Journal of Educational Social Studies. JESS 4 (1) (2015). Semarang: Universitas Negeri Semarang.

Hasan, Alwi, dkk. (2005). Kamus Besar Bahasa Indonesia. Jakarta: Departemen Pendidikan Nasional Balai Pustaka.

Irawan. Jaka, dkk. 2013. Pengaruh Kegunaan Gadget Terhadap Kemampuan Bersosialisasi pada Remaja. Jurnal An-nafs. (online). Vol. 08, No.02, (https://scholar.google.co.id/scholarjurnal+gadget+irawan+jaka\&btnG=diakses).

Irwanto. (2002). Psikologi Umum. Jakarta: PT. Prenhallindo.

Jati \& Herawati.(2014). Segmentasi Mahasiswa Program Studi Ilmu Komunikasi UAJY dalam Menggunakan Gadget. Skripsi. Yogyakarta: Fakultas Ilmu Sosial dan dan Ilmu Politik Universitas Atma Jaya Yogyakarta.

Kartono, K \& Gulo, D. (2000). Kamus Psikologi. Bandung: Pionir Jaya.

Karuniawan, A. \& Cahyanti, I.Y. (2013). Hubungan Antara Academic Stress dengan Smartphone Addiction pada Mahasiswa Pengguna Smartphone. Jurnal Psikologi Klinis dan Kesehatan Mental. Vol. 2, No. 1, April 2013. Surabaya: Fakultas Psikologi Universitas Airlangga Surabaya.

Kominfo. (2017). Survey Penggunaan TIK 2017, Serta Implikasinya Terhadap Aspek Sosial Budaya Masyarakat. Jakarta: Kementrian Komunikasi dan Informasi Republik Indonesia.

Kotler, P. \& Kevin L.K. (2007) Manajemen Pemasaran Jilid 2 Edisi 12. Jakarta: Penerbit Erlangga.

Kwon, M., dkk. 2013. The Smartphone Addiction Scale: Development and Validation of a Short Version for Adolescent. PloS ONE 8, 1-4. doi: 10,1371/journal.pone.0083558. South Korea: The Catholic University of Korea.

Latipun. (2001). Psikologi Konseling. Malang: UMM Press.

Lubis, N.L. 2016. Memahami Dasar-Dsar Konseling dalam Teori dan Praktik. Jakarta: Kencana.

Mahardika, D. 2014. Upaya Mengatasi Penyalahgunaan Gadget dalam Proses Belajar Mengajar di Kelas X TKI-1 dengan Konseling Kelompok dengan Teknik Pengkondisian Aversi. Skripsi. Kudus: Fakultas Keguruan dan Ilmu Pendidikan Universitas Kudus.

Manumpil, M. dkk. 2015. Hubungan Penggunaan Gadget dengan Tingkat Prestasi Siswa di SMA Negeri 9 Manado. Ejournal Keperawatan. Vol. 2, No. 2. Manado: Universitas Sam Ratulangi.

Matondang, R.I. (2015). Intensitas Penggunaan Gadget (Handphone) Pada Remaja: Karakteristik yang Mempengaruhi dan Dampak yang Ditimbulkan. Skripsi. Yogyakarta: Fakultas Psikologi Universitas Ahmad Dahlan.

Mappiare, Andi. (2006). Kamus Istilah Konseling dan Terapi. Jakart: PT Raja Grafindo.

Maslim, R. (2013). Buku Saku Diagnosis Gangguan Jiwa. Rujukan Singkat dari PPDGJ - III dan DSM-5. Jakarta. PT. Nuh Jaya.

Mulyadi, M. (2016). Metode Penelitian Praktis Kualitatif dan Kuantitatif. Jakarta: Publica Press.

Muna, R.F. \& Tri P.A. (2014). Hubungan Antara Kontrol Diri dengan Kecenderungan Kecanduan Media Sosial Pada Remaja Akhir. Empati Vol.3, No. 4 (2014). Semarang: Fakultas Psikologi Universitas Diponegoro.

Namora, L.L. (2011). Memahami Dasar-Dasar Konseling dalam Teori dan Praktik. Jakarta: Kencana Prenada Media Grup.

Nurihsan. (2012). Landasan Bimbingan dan Konseling. Bandung: PT. Remaja Rosdakarya.

Papalia, D.E., Old, S.W., \& Fieldman, R.D. 2008). Human Development (Terjemahan). Jakarta: Kecana.

Pendey, C.M., Ratag, B.T. \& Ismanto, Y.A. (2017) Hubungan Lama Penggunaan Gadget dengan Kejadian Insomnia pada Siswa Siswi di SMA Negeri 1 Kawangkoan. E-Journal Keperawatan, 5(1), 1-5, (https://www.e-jurnal.com/2018/05/hubungan-lamapenggunaan-gadget-dengan.html).

Prayitno. (2004). Layanan Bimbingan Kelompok dan Konseling Kelompok. Padang: Universitas Padang.

Purwanto, E., Atina, V., \& Desylawati, E.S. (2017). Sistem Pakar Deteksi Dini Gangguan Mata dan Syaraf Akibat Penggunaan Smartphone. Journal Informatika Upgris, 3(2), 152-162. Semarang: Universitas PGRI Semarang. 
Ramadhani, dkk. (2019). Pelatihan Kontrol Diri untuk Mengurangi Kecenderungan Internet Gaming Disorder Pada Anak Usia Sekolah. Jurnal Ilmiah Psikologi Terapan. Vol. 07, No. 01, Januari 209. Malang: Fakultas Psikologi Universitas Muhammadiyah Malang.

Riani, V. F. (2016). Gambaran Ketergantungan Smartphone Terhadap Produktivitas Kerja Pada Pekerja CV. Traveline Citra Nusantara Yogyakarta. Skripsi. Yogyakarta: Fakultas Psikologi Universitas Sanata Dharma.

Sa’adah. (2015). Dampak Penggunaan Gadget Terhadap Perilaku Sosial Siswa Di MAN Cirebon 1 Kabupaten Cirebon. Skripsi. Cirebon: Fakultas Ilmu Tarbiyah dan Keguruan Institut Agama Islam Negeri (IAIN) Syekh Burjati Cirebon.

Santrock, J. W. (2014). Adolescence (15th ed.). Penerjemah: Benedictine Widyasinta. Jakarta: Erlangga.

Sari, I.M., \& Prajayanti, E.D. (2017). Peningkatan Pengetahuan Siswa SMP Tentang Dampak Negatif Game Online Bagi Kesehatan. Gemassika, 1(2), 31-39. Surakarta: STIKES ‘Aisyiyah Surakarta.

Steel, P. (2007). The nature of procrastination: A meta analytic and theoretical review of quintessential self regulatory failure. Psychological Bulletin. 133(1), 65-94. Washington, DC: American Psychological Association.

Sugiono. (2012). Metode Penelitian Kuantitatif dan R\&D. Bandung: Alfabeta

Thalib, S.B. (2017). Psikologi Pendidikan Berbasis Analisis Empiris Aplikatif. Jakarta: Kencana.

Tohirin. (2007) Bimbingan Konseling di Sekolah dan Madrasah. Jakarta: Raja Grafindo Persada.

Triapambudi, B. \& Endang S.I. (2018). Hubungan Antara Kontrol Diri dengan Perilaku Konsumtif Pembelian Gadget Pada Mahasiswa Industri Universitas Diponegoro. Jurnal Empati, April 2018, Volume 7 (Nomor 2), Halaman 189. Semarang: Fakultas Psikologi Universitas Diponegoro.

Widjaja, A.K. (2015). Gambaran Celebrity Worships pada Dewasa Awal di Jakarta. Humaniora. Vol 6, no.1. BINUS University: Program studi Psikologi Fakultas Humanities.

Widyawati I., Sugiman, H., \& Edy (2014). Pengaruh Penggunaan Gadget Terhadap Daya Kembang Anak. Jakarta: Universitas Budi Luhur.

Winoto, H. (2013) Dampak Penyalahgunaan Teknologi Komunikasi Ponsel dan Gadget Pada Anak dan Remaja [Online]. Available: ttp://jurnalilmiahtp2013.blogspot.co.id/2013/12/dampak-penyalahgunaan-teknologi.html.

Zulkarnain, S. (2002). Hubungan kontrol diri dengan kreativitas Pekerja. Sumatera Utara: USU Digital Library.

\section{AUTHORS}

First Author - Nury Fitri Astuti, Clinical Professional Psychology Master Student, Universitas Ahmad Dahlan Yogyakarta, nuryfitri23@gmail.com

Second Author - Siti Urbayatun, Lecturer, Universitas Ahmad Dahlan Yogyakarta, siti.urba@gmail.com 